\title{
Location of laricinan in compression wood tracheids
}

\author{
WIESŁAW WŁOCH, ZYGMUNT HEJNOWICZ \\ Department of Biophysics and Cell Biology, Silesian University, \\ Jagiellońska 28, 40-032 Katowice, Poland
}

(Received: April 25, 1983. Revision accepted: June 8, 1983)

\begin{abstract}
It was checqued whether laricinan occurs in the helical cavities of the $\mathrm{S}_{2}$ layer of compression tracheids. It was found to be located between the lignified helical ribs of this layer. Owing to the ability of laricinan to swell, its location has a great influence on the behaviour of compression wood.
\end{abstract}

Key words: compression wood, helical cavities, laricinan, lignin.

Compression wood contains $2-4 \%$ of acidic $\beta$-D-1,3-glucan called laricinan ( $\mathrm{H}$ of fmann and Timell 1970, Timell 1982). Brodz$\mathrm{ki}$ (1972) and W $ł$ o c h (1975) studied some compression wood tracheids in respect to the occurrence of a material which produced bright yellow fluorescence after treatment with anilin blue (J ensen 1962). They referred to this fluorescent material as callose, in the broad meaning of this term as used in plant anatomy and embryology. Surely it was laricinan.

According to $\mathrm{Brodzki}(1972)$ and $\mathrm{W} ł o \mathrm{ch}$ (1975) the glucan occurs in the helical cavities of the $\mathrm{S}_{2}$ layer of compression tracheids. The location is important in view of the concept that the glucan located in the cavities generates longitudinal stresses underlying the tendency of compression wood to expand on maturation and to shrink while drying. This concept is based on: 1) the ability of callose to imbibe a considerable amount of water (E s chrich 1965) shared also by laricinan (Fig. 3), and 2) a working hypothesis that the ability of the glucan to swell may be increased after its deposition in the cavities, owing to enzymatic partial hydrolysis (this hypothesis has not been explicitly advanced in the mentioned paper) W $\mathrm{foch}$ (1975) observed a relation between longitudinal shrinkage and glucan accumulation in the wall. Boyd (1978) claimed that it is improbable that such a glucan could be a primary 
PLATE I

Fig. 1. Pinus strobus compression wood from the bottom; a 2-year-old branch. Transection $1 \mu \mathrm{m}$ thick. A - yellow fluorescence after treatment with anilin blue; B - the same fragment in white light after treatment with phloroglucinol and $\mathrm{HCl}$. Gray colour in the photograph corresponds to pink on the section. The parts which produce fluorescence do not show pink colour

Fig. 2. The same as Fig. 1., but for the oblique (transverse-radial) section. On the left side of the cell centre the helical ribs are perpendicular to the section plane

Fig. 3. Disintegrated fragments of different layers of the compression wood wall of Picea excelsa when dry and photographed in white light (A). When thereafter wetted with anilin blue solution, yellow fluorescence was photographed (B). Fragment 1 in the photograph $3 \mathrm{~B}$ shows bright yellow fluorescence indicating that it is rich in laricinan, fragments 2-4 show only weak fluorescence which idicates that they correspond to other layers than $\mathrm{S}_{2}$ (additional test with phloroglucinol has indicated that the nonfluorescent fragments are rich in lignin, while the fluorescent fragment contains much less lignin). The swelling of the fluorescent fragments was much more pronounced (compared with the same fragments in the photograph 3A) than swelling of nonfluorescent ones. (Scrapings of compression wood were disingrated by means of ultrasounds. A drop of suspension was dried on a slide, at $45^{\circ} \mathrm{C}$ overnight, photographed under a coverglass but without any fluid addition (Fig. 3A). Thereafter a drop of anilin blue was introduced under the coverglass and the slide was photographed again for yellow fluorescence, Fig. 3B). Black and white sectors on all the photographs denote a length of $10 \mu \mathrm{m}$

factor responsible for the capacity of compression wood to generate unusually large longitudinal stresses associated with a reorientation movement of wood stems. He expressed doubts whether Brodzki and Włoch's interpretation of the location of glucan within the cell wall is correct. We checked, therefore, once more the location of laricinan, and additionally lignin. The occurrence of the latter one was checqued by the use of the phloroglucinol method. No doubt is left that laricinan occurs between the ribs containing lignin in the $\mathrm{S}_{2}$ layer, thus, in the places which are called "helical cavities".

The location of laricinan within the cell wall is such that it fits the hypothesis of the stress-generating role of glucan, though obviously this does not prove the hypothesis. It must be verified whether this hypothesis is correct by comparative studies and experiments with callase (on the condition that it acts on acidic glucan). The objections raised by Boyd are very interesting, however, it is our opinion that they do not make the hypothesis improbable. Our experience indicates that the reorientation based on compression wood seems to be controlled not only by the amount of the compression wood, not only by the micrfibril angle, but also by properties which seem to be related to state of glucan. It is not generally a recognized fact that not all compression wood develops an expansive tendency as soon as it is laid down by cambium 


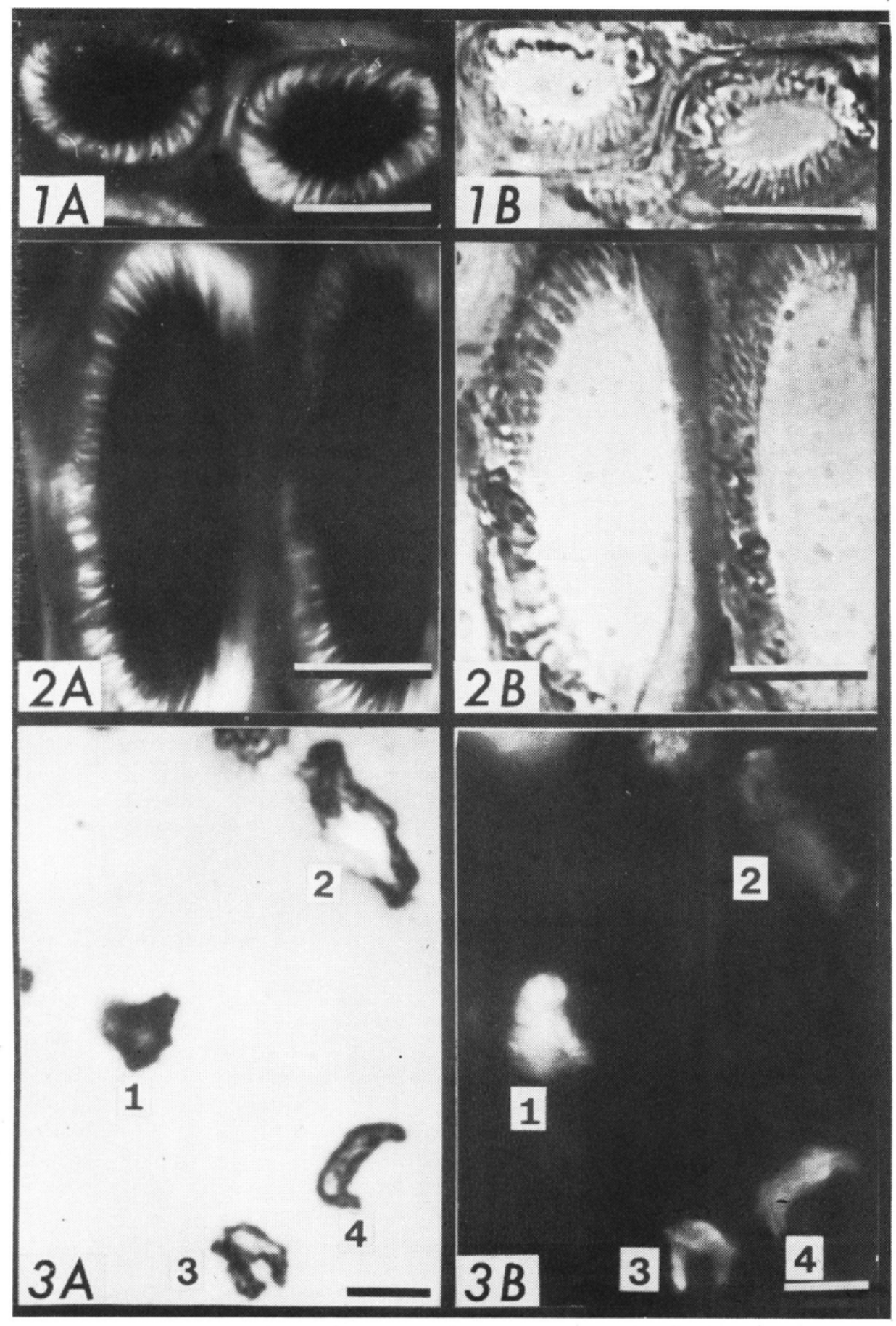


(Hejnowicz 1967). Immediate expasion has been observed in this stems but not in thick ones. Preliminary observation indicates that in thick inclined stems the compressive wood is neutral at first, but after being accumulated it undergoes en masse changes which bring about its expansive tendency which can then be high enough to cause reorientation bending of the stem. The glucan, the ability of which to swell can be enhanced, seems to be especially suited to play a role in the reorientation. It is a very intriguing strategy of reorientation in woody stems which we began to study several years ago, but then for technical reasons the study was interrupted.

\title{
REFERENCES
}

B o y d J. D., 1978. Significance of Laricinan in Compression Wood Tracheids. Wood Sci. Technol. 12: 25-35.

Brodzki P., 1972. Callose in compression wood tracheids. Acta Soc. Bot. Pol. 41: $321-327$.

Eschrich W., 1965. Physiologie der Siebröhrencallose. Planta 65: 280-300.

Hejnowicz Z., 1967. Some observations on the mechanisms of orientation movements of woody stems. Amer. J. Bot. 54: 684-689.

$\mathrm{H}$ of $\mathrm{fmann}$ G. C., T i mel1 T. E., 1970. Isolation of a $\beta$-1,3-glucan (laricinan) from compression wood of Larix laricina. Wood Sci. Technol. 4: 159-162.

J ensen W. A., 1962. Botanical histochemistry. W. H. Freeman and Company. San Francisco and London.

Timell T. E., 1982. Recent Progress in the Chemistry and Topochemistry of Compression Wood. Wood Sci. Technol. 16: 83-122.

W $10 \mathrm{ch}$ W., 1975. Longitudinal shrinkage of compression wood in dependence on water content and cell wall structure. Acta Soc. Bot. Pol. 44: 217-229.

\section{Rozmieszczenie laricinanu $w$ cewkach drewna kompresyjnego}

\author{
Streszczenie
}

Sprawdzono, czy laricinan występuje $\mathrm{w}$ spiralnych szczelinach warstwy $\mathrm{S}_{2}$ ścian cewek kompresyjnych. Laricinan zlokalizowany jest wewnątrz warstwy $\mathrm{S}_{2}$ w spiralnych szczelinach między zdrewniałymi żeberkami tej warstwy. Ze względu na zdolność do pęcznienia laricinanu jego rozmieszczenie ma istotny wpływ na zachowanie się drewna kompresyjnego.

* Note added in the proof:

Most pertinent to the topic is the paper by L. Waterkeyn, S. Caeymaex and E. Decamps, 1982 (La callose des trachéides du bois de compression chez Pinus silvestris et Larix decidua. Bull. Soc. Roy. Bot. Belg. 115: 149-155), which shows accurate localization of the callose. On semi-thin cross sections the 3-linked glucan forms isolated radial oriented streaks in the $\mathrm{S}_{2}$ layer. 